AVANT, wol. IX, nr 1/2018

ISSN: 2082-6710 avant.edu.pl/en

DOI: $10.26913 / 90102018.0103 .0004$

оrma

\title{
Realizm prawniczy a pozytywizm prawniczy ${ }^{1}$
}

\author{
Adam Dyrda \\ Uniwersystet Jagielloński w Krakowie \\ adam.dyrda@uj.edu.pl \\ Przyjęto 12 grudnia 2017; zaakceptowano 21 stycznia 2018; opublikowano 14 marca 2018.
}

\begin{abstract}
Amerykański realizm prawniczy jest powszechnie traktowany jako teoria-parias. W artykule zostają przedstawione możliwe przyczyny takiego stanu rzeczy. Ogólnie rzecz biorąc, protekcjonalna i dyskredytująca postawa przedstawicieli tak zwanej ogólnej jurysprudencji wobec realizmu wynika z niezrozumienia jego podstawowych celów, co rzutuje na błędne określenie relacji między nim a teoriami ogólnymi, w szczególności zaś pozytywizmem prawniczym. W pierwszej części tekstu wyjaśnia się, jakie były te cele i jak należy postrzegać te relacje. Natomiast w drugiej krótkiej analizie zostaje poddany pogląd Briana Leitera, zgodnie z którym realizm zakładał pewne twierdzenia pojęciowe twardego pozytywizmu prawniczego. Krytyka tego poglądu otwiera możliwość przedstawienia alternatywnej interpretacji wysiłków realistów.
\end{abstract}

Slowa kluczowe: pozytywizm prawniczy; amerykański realizm prawny; truizmy o prawie; ogólna teoria prawa; teoria stosowania prawa; Brian Leiter.

Realizm prawniczy², szczególnie w wydaniu amerykańskim, stanowi dziś nieco zapomniany nurt jurysprudencji. Nawet jeśli we współczesnej literaturze teoretycznoprawnej

\footnotetext{
${ }^{1}$ Artykuł został napisany w związku z realizacją grantu Sonata zatytułowanego „Nowa krytyka amerykańskiego realizmu prawnego" o numerze 2016/21/D/HS5/03839, który przyznało Narodowe Centrum Nauki.

${ }^{2}$ Pisząc o realizmie prawniczym, mam na myśli nurt (bo trudno nazwać go „szkołą”, nawet w bardzo szerokim sensie tego słowa), amerykańskiej myśli prawniczej, który największą popularność zyskał w latach 30. i 40. XX wieku. Za głównych przedstawicieli należy uznać: O. W. Holmesa, Jr., K. Llewellyna, J. Franka, M. Radina, U. Moore'a, H. Yntemę, F. Cohena, J. Binghama, H. Lasswella, W. Hamiltona, T. Schroedera, M. Rheinsteina, E. Laskiego, E. Garlana, T. Powella, W. Douglasa, H. Oliphanta, L. Greena, J. Hutchesona, T. Arnolda, a także - R. Pounda. Zasadnicze cechy realizmu, który nie stanowił żadnego zwartego nurtu, sprowadzić można do: (1)
} 
pojawiają się jakieś odwołania do myśli amerykańskich realistów prawniczych, to często towarzyszą im liczne nieporozumienia (Dyrda, 2014a). Można odnieść wrażenie, że amerykański realizm prawniczy od lat traktuje się jak pariasa na polu prawoznawstwa ${ }^{3}$ : twierdzi się, że poglądy realistów amerykańskich w ogóle wymykają się tradycyjnemu odróżnieniu pozytywistycznych i prawnonaturalnych teorii prawa (tworzących swoisty prawoznawczy „system kastowy”) albo że realiści amerykańscy tak naprawdę po cichu zakładali pewną ogólną, pozytywistyczną teorię prawa (w tym sensie byli de facto pojęciowo zależni od pewnej „kasty wyższej”, reprezentowaną przez teorię pozytywistyczną), albo wreszcie, że twierdzenia realistów, zrekonstruowane w postaci ogólnej teorii prawa są tak nieprzekonujące, że stanowią teoretycznoprawny dowcip (jurisprduential joke; por. Leiter, 2001, s. 278). W pierwszym przypadku realizm okazuje się nie być teorią prawa, o której warto dyskutować. W drugim okazuje się być teorią tylko dlatego, że z innej, poważnej teorii czerpie garściami - uznaje się go za teorię, która jest nieświadoma własnych pojęciowych założeń. W trzecim uznawany jest za teorię aspirującą do bycia rywalem pozytywizmu i różnych wersji non-pozytywizmu (teorii prawa natury, teorii Dworkina), która jednak nie wytrzymuje krytyki - traktuje się go jako teorię „dziecinną”, kompromitującą się niedojrzałością własnych tez. We wszystkich tych przypadkach zatem realizm prawniczy nie zostaje potraktowany z powagą, na jaką niewątpliwie zasługuje.

W tym artykule chciałbym rozważyć wskazane interpretacje, które prowadzą do pojmowania realizmu prawniczego jako teorii-pariasa. Ich przedstawieniu towarzyszy intencja zbadania, w jakim zakresie, jeśli w ogóle, realiści prawniczy, niejako chcąc nie chcąc, nieświadomie, lecz intuicyjnie, zakładali pozytywistyczne pojęcie prawa. Ta ostatnia teza zyskała na popularności dzięki wystąpieniu Briana Leitera. Jak będę starał się dowieść, popularność znajduje ona zasadniczo w kręgach... pozytywistycznych. Nie będę starał się tej tezy obalać, nie sądzę bowiem, aby w sferze rozważań teoretycznych jej proste obalenie było w ogóle możliwe. Zamiast tego postaram się przedstawić alternatywną interpretację wysiłków realistów jako nieopierających się na założeniach pozytywizmu prawniczego, poza pewnym jego trywialnym i mało interesującym rozumieniem.

\footnotetext{
przyjęcia perspektywy praktyki prawa, skutkującego badaniem ,prawa w działaniu” (law in action) oraz (2) uporczywego wręcz podkreślania, że prawo nie stanowi zbioru re g u 1, lecz zbiór fa k t ó w, które można zaobserwować w działaniach urzędników, sędziów i innych funkcjonariuszy systemu prawa (por. Paul, 1959, s. 24). Jak wskazuje Leiter, realiści zasadniczo akceptowali pewną deskryptywną teorię orzekania (descriptive theory of adjudication), zgodnie z którą w trakcie orzekania sędzia r e a g u j e przede wszystkim na fakty (okoliczności) sprawy, niekoniecznie zaś na ustanowione reguły i „,racje prawne”, które są zwykle powoływane przez sędziów, aby u z a s a d n i ć podjętą już decyzję (Leiter, 1999, s. 1148).

${ }^{3}$ Za pariasa traktowany był w ostatnich latach nie tylko realizm prawniczy, ale także pozytywizm prawniczy (por. Schauer, 1996). Jednakże w tym przypadku było to wyłącznie rezultatem powszechnej nieznajomości twierdzeń pozytywistycznych, która skutkowała tym, że błędnie utożsamiano pozytywizm z teorią, która u s p r a w i e d li w i a ła zbrodnicze reżimy prawne. Jest jednak jasne, że pozytywizm jako teoria opisowa nie ma na celu niczego u s p ra wi ed li wi ać czy u za sa d n i ć.
} 
Pierwsza interpretacja realizmu, zgodnie z którą realizm wypada w ogóle poza prawoznawczy „system kastowy”, znajduje częściowe umocowanie we własnych twierdzeniach realistów amerykańskich. Utożsamiali oni bowiem błędnie pozytywizm prawniczy, który właściwie powinien być rozumiany jako ogólna teoria prawa, z formalizmem prawniczym, który właściwie rozumiany stanowi jedynie teorię orzekania (stosowania prawa). Mówiąc w uproszczeniu, pozytywizm prawniczy odpowiada na pytanie „,co to jest prawo?”, przy tym udzielane przez pozytywizm prawniczy odpowiedzi opierają się na pewnych założeniach metafizycznych (por. Gizbert-Studnicki, Dyrda, Grabowski, 2016, s. 21-195) co do „,natury” bądź ,istoty” prawa, choć w żadnym razie nie stanowią prób przedstawienia wyczerpującej definicji tego pojęcia ${ }^{4}$. Pozytywiści, wyjaśniając, czym prawo jest, odwołują się do pewnych oczywistych, powszechnie akceptowanych truizmów o prawie, takich jak truizm o społecznym pochodzeniu prawa, truizm o kontynuacyjnym charakterze prawa (prawo trwa w czasie) czy truizm o braku koniecznego powiązania prawa i moralności ${ }^{5}$. Dla pozytywistów przykładem prawa, który stanowi punkt wyjścia dla dalszych analiz pojęciowych, są zwykle akty prawne lub precedensy o amoralnym - albo nawet niemoralnym - charakterze, których autorem jest jednak uprawniony do tego organ (i w związku z tym przeszły pewien społeczny ,test pochodzenia”). To podejście odpowiada z kolei potocznej intuicji, że prawo może być niemoralne, ciągle pozostając prawem ${ }^{6}$.

Pozytywizm prawniczy jest zatem ogólną teorią prawa. Pozytywistów interesuje odpowiedź na pytanie, czym jest prawo, nie interesują ich natomiast teorie stosowania prawa, w szczególności zaś teorie, które określają, w jaki sposób sędziowie wydają lub powinni wydawać decyzje prawne (teorie orzekania). W szczególności pozytywizm nie przesądza, w jaki sposób sędziowie powinni korzystać ze źródeł prawa (w szczególności - w jaki sposób powinni je interpretować), nie zakazuje on też sięgania przez sędziów w procesie podejmowania decyzji do źródeł pozaprawnych. Pozytywiści, pozostając bezstronnymi w kwestii doboru właściwej teorii stosowania prawa, tkwią jednak uparcie przy pewnego rodzaju pojęciowym twierdzeniu: mianowicie, że każda taka teoria, jeśli w ogóle ma być

\footnotetext{
${ }^{4}$ Mowa tutaj o teorii pozytywistycznej rozwijanej przez Harta i jego kontynuatorów.

${ }^{5}$ Odwołania explicite do truizmów na gruncie teorii prawa stanowią pewną nowość (w tej kwestii por. GizbertStudnicki, Dyrda, Grabowski, 2016, s. 220 i n.; Shapiro, 2011, s. 8; Spaak, 2016). Zasadniczo jednak da się zrekonstruować starsze ogólne teorie prawa (zarówno pozytywistyczne, jak i niepozytywistyczne) jako oparte czy też odwołujące się do wybranych zbiorów truizmów o prawie (w tej kwestii por. Gizbert-Studnicki, Dyrda, Grabowski, 2016, s. 145 i n. oraz Dyrda, 2017, s. 141-322; 323-342; 367-382).

${ }^{6}$ Pozytywizm prawniczy, jako pogląd na temat pojęcia czy też natury prawa, jest teorią, która stanowi klarowny punkt wyjścia dla doktryn nieposłuszeństwa obywatelskiego z tej przyczyny, że aby móc protestować, trzeba najpierw określić przeciwko c z e m u chce się protestować. Jednakże także na gruncie innych, nie-ogólnych teorii, np. teorii typu realistycznego, zgodnie z którymi prawem są decyzje sędziowskie (decyzje instytucji), możliwe jest zbudowanie teorii nieposłuszeństwa obywatelskiego, tj. nieposłuszeństwa rozumianego po prostu jako sprzeciw przeciwko tym właśnie decyzjom (a nie ich u z a s a d n i e n i u, podstawom itp.).
} 
teorią stosowania p r a wa, to musi rozpoznawać c oś jako prawo, a zatem przyjąć pewne pojęciowe założenia dotyczące natury prawa. Założenia te można uznać za „oczywiste”, sam pozytywizm zaś - jeśli zastosować określenie Michaela Moore’a - za teorię prawa oczywistego (obvious law; Moore, 2012). Upierają się przy tym, że proponowane przez nich określenie natury prawa jest najwłaściwsze. Można więc powiedzieć, że pozytywizm pozostaje indyferentny w kwestii doboru teorii orzekania, o ile teoria ta akceptuje, albo przynajmniej nie kwestionuje, podstawowych założeń pojęciowych pozytywizmu. W przeciwnym przypadku pozytywiści skłonni są raczej krytykować przyjmowane przez tę teorię założenia (jako niezgodne z pozytywistycznymi), a nie - krytykować ją za to, że stanowi teorię orzekania ${ }^{7}$.

Wspomniane wyżej utożsamienie przez realistów amerykańskich pozytywizmu i formalizmu miało tę przykrą konsekwencję, że odrzucając formalizm prawniczy, realiści odcinali się także od pozytywizmu prawniczego. Leiter wskazuje, że zarówno termin ,pozytywizm”, jak i termin „formalizm” są - i było tak także w czasach realistów prawniczych (czyli w pierwszej połowie XX wieku) - często używane jako epitety, czemu nie towarzyszy(ło) w zasadzie żadne głębsze, jednolite ich rozumienie (Leiter, 1999, s. 1444). Niemniej jednak, jak wskazuje Leiter, możliwe jest zrekonstruowanie zasadniczych tez formalizmu prawniczego jako opisowej teorii orzekania w postaci następujących twierdzeń: (1) prawo jest w całości racjonalnie zdeterminowane, (2) sądzenie ma charakter „mechanistyczny”, (3) rozumowania prawnicze mają charakter autonomiczny, istnieje bowiem klasa autonomicznych „racji prawnych” (legal reasons), które zawsze uzasadniają jeden właściwy rezultat (Leiter, 1999, s. 1145-1146). Zgodnie z tak zrekonstruowanym poglądem formalistycznym, racje, które uznaje się za prawne, wystarczają dla uzasadnienia każdej poprawnej decyzji sądu. Wedle formalistów sędzia nie dysponuje żadnym zakresem uznania (dyskrecjonalności), gdyż prawo zawsze determinuje jedno rozstrzygnięcie prawne.

Pogląd formalistyczny już na pierwszy rzut oka wydaje się dla pragmatycznie nastawionych filozofów prawa nie do przyjęcia. Takie wrażenie jest jednak złudne, ponieważ rozstrzygnięcie tej kwestii zależy od tego, jaką ogólną teorię prawa nastawiony fo r m a listycznie filozof prawa przyjmie. Jak słusznie wskazuje Leiter, przyjęcie powyższego rozumienia formalizmu prowadzi do tego, że należy uznać za naczelnego współczesnego formalistę Ronalda Dworkina, gdyż jego teoria law-as-integrity nie pozostawia żadnego pola dla tradycyjnie rozumianej dyskrecjonalności sędziowskiej. Idealny

\footnotetext{
${ }^{7}$ Pozytywiści odróżniają prawnicze „rozumowania o prawie” (reasoning about law), a więc w szczególności analizy pojęcia prawa, od „rozumowań na podstawie prawa” (reasoning according to law), które obejmują rozumowania dotyczące interpretacji prawa. Pierwsze stanowią zatem domenę badań teoretyczno-prawnych, w wyniku których możliwa jest m.in. źródłowa identyfikacja norm prawnych. Drugie natomiast stanowią rozumowania prowadzące do praktycznych konkluzji (decyzji stosowania prawa), które mogą być podjęte na podstawie zarówno źródeł prawnych, jak i poza-prawnych (argumenty moralne, praktyczne). Pozytywiści uznają, że wobec takich pozaprawnych ,racji prawnych” instytucje systemu prawa mają jedynie władzę ,,aplikacyjną”, a nie „kreacyjną” (por. Raz, 2004, s. 17; Green, 2009).

${ }^{8}$ Morris Cohen nazwał tego rodzaju formalizm sędziowski „teorią fonograficzną” (phonographic theory; por. Paul, 1959, s. 16).
} 
sędzia Herkules potrafi, na gruncie koncepcji Dworkina, zawsze, w każdej sprawie, znaleźć jedyne właściwe rozwiązanie. To, co odróżnia Dworkina od innych formalistów, to po prostu fakt, że na gruncie jego teorii prawa klasa „racji prawnych” jest znacznie szersza niż w przypadku innych formalistów (Leiter, 1999, s. 1146). Co więcej, teoria Dworkinowska w zasadniczym stopniu opiera się na metodologicznych założeniach pragmatyzmu (co widoczne jest w krytyce analizy pojęciowej, przyjęciu metodologii holistycznego pragmatyzmu i implementacji Rawlsowskiej idei „refleksyjnej równowagi”; por. Dworkin, 2006, s. 151). Wygląda więc na to, że najsłynniejszy współczesny niepozytywista był $\mathrm{w}$ zasadzie formalistą.

Trudno jest natomiast wskazać z nazwiska formalistycznie nastawionych pozytywistów. Nie jest to bowiem powiązanie szczególnie wiarygodne, a tym bardziej konieczne. Klasa racji prawnych w przypadku teorii pozytywistycznych (teorii „prawa oczywistego”) jest nad wyraz szczupła. Ponadto, z uwagi na rozpoznane przez pozytywistów własności języka (takich jak jego otwarta struktura, open texture), nawet fakt konwencjonalnego określenia szczególnej domeny „odseparowanych” racji prawnych (limited domain of law; por. Schauer, 2004) nie pozwala na eliminację dyskrecjonalności. Wobec tego, choć pozytywiści nie przesądzają o tym, jaka teoria orzekania jest właściwa, należy raczej odmówić im inklinacji formalistycznych. Zresztą najsłynniejszy współczesny pozytywista prawniczy, H. L. A. Hart, z całą pewnością formalistą nie był (trudno też do formalistów w powyższym sensie zaliczyć jego pozytywistycznych uczniów, kontynuatorów czy krytyków).

Wygląda więc na to, że krytyka pozytywizmu jako formalizmu jest wynikiem pomieszania pojęciowego, wynikającego przede wszystkim z braku rozróżnienia twierdzeń ogólnej teorii prawa i teorii orzekania. Jest raczej oczywiste, że dla swej codziennej pracy każdy prawnik musi przyjmować, choćby milcząco, pewne ogólne założenia pojęciowe, a także - niekoniecznie bardziej świadomie - pewną teorię orzekania. Z filozoficznego punktu widzenia ważne jest jednak, aby na tyle uważnie rozważać pewne ogólne poglądy filozoficzne na temat prawa, by teoriom ogólnym nie imputować konsekwencji w postaci twierdzeń na temat sfery orzekania. Teorie pozytywistyczne z całą pewnością tego nie robią. Nie oznacza to jednak, że takie - kompleksowe, to jest łączące obie sfery teoretyczne teorie nie istnieją: dobitnym przykładem jest wskazana wyżej teoria Dworkina.

Wydaje się jednak, że źródło tego pomieszania pojęciowego, przynajmniej w przypadku samych realistów prawniczych, może wynikać nie tylko z niezrozumienia natury pozytywizmu prawniczego, ale także - co może nawet bardziej istotne - z bardzo szerokiego, popularnego wśród pragmatystów i progresywistów pierwszej połowy XX wieku rozumienia „formalizmu”. Za formalistyczny - w tym szerokim rozumieniu - uchodził każdy pogląd ,abstrakcjonistyczny”, manifestujący przywiązanie do ustalonych definicji (dogmatów) pojęciowych, prawd apriorycznych czy oczywistych (self-evident truths). Jak wskazuje Morton White, tak zwana rewolta przeciw formalizmowi (revolt against formalism), której apostołami byli myśliciele tacy jak Charles A. Beard, John Dewey, Oliver Wendell Holmes Jr., James Harvey Robinson czy Thorstein Veblen, polegała na odrzuceniu twierdzenia o odpowiedniości metod logicznych, abstrakcji, dedukcji, matematyki czy nawet 
mechaniki - dla wyjaśniania i przewidywania zjawisk w obrębie nauk społecznych (White, 1949). Protorealista prawniczy Holmes przecież kładł nacisk na to, że prawo winno ucieleśniać historię narodu, w związku z czym decyzje prawne nie mogą być prostym rezultatem dedukcji z abstrakcyjnych pojęć, reguł i precedensów (jak chcieli zwolennicy tzw. Langdellowskiej ortodoksji; por. Holmes, 1897). Veblen argumentował, że dla przeprowadzenia skutecznych analiz procesów społecznych (w tym ekonomicznych) konieczne jest odwołanie się do wyników badań antropologicznych (Veblen, 1898). Beard, autor kontrowersyjnej interpretacji Konstytucji USA, twierdził, że badanie relacji formalno-prawnych musi obejmować badanie źródeł (procesów) społecznych, w kontekście których się one uformowały (Beard, 1921). Robinson uważał, że praca historyka powinna być wolna od moralizowania i estetyzowania, a jednocześnie ukierunkowana na przedstawienie, w jaki sposób do pewnych zdarzeń doszło (Robinson, 1908). W końcu trzeba wymienić Deweyowską krytykę abstrakcyjnych poglądów filozoficznych (empiryzm brytyjski) czy przestarzałych form edukacji (m.in. Dewey, 1891, 1899, 1929) - te i wyżej wskazane poglądy znajdują swoje pozytywne odzwierciedlenie w pragmatycznych ideach ewolucji i refleksji, których szeroko rozumiany, abstrakcyjny, pojęciowy, mechaniczny, gwarantujący pewność wyników teoretycznych „, „formalizm” ma być zaprzeczeniem. Poglądy wskazanych myślicieli były wymierzone przeciwko popularnym, lecz sztucznym wizjom „człowieka intelektu”, „człowieka prawnego”, „człowieka ekonomicznego” i „obiektywnego historyka”, które to pojęcia stanowiły dla pragmatystów czyste abstrakcje.

Realiści prawniczy uprawiali filozofię prawa w tym właśnie ,,antyformalistycznym” duchu, starając się uwolnić rozważania o prawie od metafizycznych ciężarów i ograniczeń, jakie nakładały tradycyjne doktryny prawnicze. Należy przy tym zauważyć, że krytykowany przez nich formalizm prawniczy w wyżej zdefiniowanym sensie - rozumiany jako teoria orzekania - jest z całą pewnością przykładem postawy „formalistycznej” w sensie

\footnotetext{
${ }^{9}$ Dewey w The Quest for Certainty pisał: „The quest for certainty is a quest for a peace which is assured, an object which is unqualified by risk and the shadow of fear which action casts. For it is not uncertainty per se which men dislike, but the fact that uncertainty involves us in peril of evils. Uncertainty that affected only the detail of consequences to be experienced provided they had a warrant of being enjoyable would have no sting. It would bring the zest of adventure and the spice of variety. Quest for complete certainty can be fulfilled in pure knowing alone. Such is the verdict of our most enduring philosophic tradition. While the tradition has, as we shall see later, found its way into all themes and subjects, and determines the form of current problems and conclusions regarding mind and knowledge, it may be doubted whether if we were suddenly released from the burden of tradition, we should, on the basis of present experience take the disparaging view of practice and the exalted view of knowledge apart from action which tradition dictates. For man, in spite of the new perils in which the machinery of his new arts of production and transportation have involved him, has learned to play with sources of danger. [...] We have attained, at least subconsciously, a certain feeling of confidence; a feeling that control of the main conditions of fortune is to an appreciable degree passing into our own hands. We live surrounded with the protection of thousands of arts and we have devised schemes of insurance which mitigate and distribute the evils which accrue. Barring the fears which war leaves in its train, it is perhaps a safe speculation that if contemporary western man were completely deprived of all the old beliefs about knowledge and actions he would assume, with a fair degree of confidence, that it lies within his power to achieve a reasonable degree of security in life" (Dewey, 1929, s. 8-9).
} 
szerszym. Przyjęcie jednak nawet, zgodnie z sugestią Leitera, że utożsamienie pozytywizmu prawniczego jako ogólnej teorii prawa $\mathrm{z}$ formalizmem jest błędne oraz że formalizm jest z realistycznego punktu widzenia nie do utrzymania, pozostawia ciągle otwartą kwestię relacji między realizmem a pozytywizmem.

Wskazałem już wcześniej, że pozytywizm stanowi ogólną teorię prawa. Z kolei realizm prawniczy z całą pewnością nie stanowił ogólnej teorii prawa w takim sensie, w jakim jest nią poszukujący ,natury prawa” pozytywizm prawniczy. Realiści prawniczy zasadniczo pozostawali - zgodnie z własnymi deklaracjami - sceptykami i nominalistami. Kwestionowali oni w szczególności, w duchu szeroko rozumianego antyformalizmu, przyjmowanie pewnych apriorycznych prawd, stanowiących podstawę dla konstrukcji technicznych pojęć dyskursu prawnego. Za apostoła realizmu uchodzi zresztą pragmatysta Holmes, którego podejście Jerome Frank zrekapitulował następująco:

He did not content himself with substituting an accurate description of legal rights and duties for a false description. He pointed to the fundamental vice in most prior legal thinking. He made it clear that traditional jurisprudence is founded upon the erroneous notion - sometimes expressed but often implicit - that there are self-evident truths about the judicial process which must not be and cannot be questioned, from which self-evident truths a legal system can be worked out logically as the ancient geometers had worked out their systems from selfevident geometrical axioms. Holmes saw that law is not pure mathematics; that the so-called self-evident truths of the traditional jurisprudence are not self-evident; and that many of the axioms of legal thinking do not appear on the surface but are concealed and must be dug out for inspection (Frank, 1932, s. 571; por. Paul, 1959, s. 17).

Frank nazywał sposób myślenia Holmesa, którego podziwiał i określał mianem „w pełni dojrzałego prawnika" (completely adult jurist), wręcz myśleniem nie-euklidesowym (noneuclidean legal thinking; Frank, 1932). Holmes twierdził, że prawo nie ma apriorycznie określonej natury i że rolą teoretyka prawa winno być nie tyle poszukiwanie „,bezużytecznej kwintesencji wszystkich systemów prawnych" (useless quintessence of all legal systems), ile rzetelne przedstawienie anatomii danego systemu prawa (accuarte anatomy of one; Holmes, 1897, s. 475; por. White, 2002, s. 130). Stanowiło to zresztą przeniesienie na grunt prawny postulatu Deweya, aby zrezygnować z bezużytecznego ,dążenia do pewności” (quest for certainty; Dewey, 1929). Tego rodzaju podejście pobrzmiewa w jednej z najsłynniejszych wypowiedzi Holmesa:

The life of the law has not been logic: it has been experience. The felt necessities of the times, the prevalent moral and political theories, intuitions of public policy, avowed or unconscious, even the prejudices which judges share with their fellow-men, have had a good deal more to do than the syllogism in determining the rules by which men should be governed. (Holmes, 1881, s. 1)

Cytat ten stanowi kamień węgielny realizmu prawniczego. Należy odczytywać go jako krytykę różnych form spekulacji w praktyce prawa, które nie przynoszą żadnych praktycznych skutków. Stanowi on (dyskretną) implementację maksymy pragmatycznej Peirce'a 
na grunt prawoznawstwa ${ }^{10}$. Przy czym nie chodzi tutaj wyłącznie o krytykę ściśle formalistycznego podejścia do stosowania prawa, lecz w ogóle o krytykę tradycyjnych, dogmatycznych, to jest przywiązanych do apriorycznych prawd prawniczych sposobów myślenia, które manifestowały swoje szczególne oparcie na pewnych - wątpliwych z nominalistycznego punktu widzenia - twierdzeniach metafizycznych.

Sposobem na przełamanie monopolu dawnych, dogmatycznych teorii było wedle realistów zastosowanie nowych metod, takich jak na przykład: (1) metoda instrumentalnej inżynierii społecznej Roscoe’a Pounda, która pozwalała zrozumieć funkcjonowanie prawa w kontekście wartości, które ma realizować i celów, do których ma dążyć, uwypuklając tym samym relacje między funkcjonowaniem prawa a życiem społeczeństwa jako pewnego złożonego „organizmu” (tak zwana jurysprudencja socjologiczna) ${ }^{11}$, (2) metody instytucjonalno-antropologiczne, które uwzględniały wszystkie czynniki wpływające na kształtowanie i funkcjonowanie prawa, szczególnie w czasach dynamicznych przemian społecznych ${ }^{12}$ czy wreszcie (3) metoda asocjacji psychologicznych (free-phantasy method, jak to określał Harold Lasswell) czy po prostu „metoda psychoanalityczna” (Jerome Frank), której celem było zidentyfikowanie wszelkich podświadomych uprzedzeń i dogmatów, którymi kierują się w swej codziennej pracy prawnicy. Ta ostatnia metoda budziła najwięcej kontrowersji z uwagi na oparcie jej na założeniach freudowskiej szkoły psychoanalitycznej ${ }^{13}$.

Nie mamy tutaj miejsca, aby poświęcać więcej uwagi każdemu z tych nurtów, natomiast z punktu widzenia obecnych rozważań istotne jest wskazanie, w jaki sposób realiści odnosili się do tradycyjnych, formalistycznych w szerokim sensie, doktryn. Przytoczmy kilka cytatów.

\footnotetext{
${ }^{10}$ Peirce pisał: „rozważmy, jakie to skutki, o których da się pomyśleć, że mają praktyczny wymiar, wiążemy myślowo z przedmiotem naszej koncepcji. Nasza koncepcja tych skutków jest zatem całą naszą koncepcją tego przedmiotu" (Peirce, 1878, s. 132; t1. polskie cyt. za Szubka, 2012, s. 14).

${ }^{11}$ Choć Pound wprost deklarował, że kontynuuje myśl Holmesa, to wielu realistów, w tym Frank, uznawało go za zdrajcę, który wypaczył idee ich apostoła. Frank pisał: „Pound was the right wing of the Holmes' movement. It was in the highest degree unfortunate that the first vastly influential teacher to take over Holmes' insight should have warped it. It might almost be said that Holmes' point of view would have been less retarded today in its consequences had Pound opposed it. For his mode of partially adopting it was to confuse and mislead those whom he influenced" (Frank, 1931, s. 18).

${ }^{12}$ Tego rodzaju podejście prezentował m.in. Karl Llewellyn, który wraz z E. Adamsonem Hoebelem badał sposób funkcjonowania prawa w prymitywnym społeczeństwie Indian Czejenów (Llewellyn, 1941). W nieco węższym, ekonomicznym kontekście, tego rodzaju podejście do postrzegania funkcjonowania prawa prezentowali W. Douglas, M. C. Shanks (1927), W. H. Hamilton (1929) czy T. W. Arnold (1937). Prace te to prolegomena do popularnej współcześnie ekonomicznej analizy prawa.

${ }^{13}$ Jedną z najbardziej kontrowersyjnych książek w tym nurcie realizmu jest Law and the Modern Mind Franka (Frank, 1930).
} 
Pound pisał:

For the simple picture of the legal order painted by the historical school, with its one ideal to which it attributed and by which it solved everything, must give way before the results of psychology and psychological sociology. We must give up the quest for the one solving idea. The actual legal order is not a simple rational thing. It is a complex, more or less, irrational thing into which we struggle to put reason and in which, as fast as we have put some part of it in the order of reason, new irrationalities arise in the process of meeting new needs by trial and error. (Pound, 1946, s. 21; wyróżnienie moje)

Z kolei Frank wskazywał:

Only a limited degree of legal certainty can be attained. The current demand for exactness and predictability in law is incapable of satisfaction because a greater degree of legal finality is sought than is procurable, desirable or necessary. If it be true that greater legal certainty is sought than is practically required or attainable, then the demand for excessive legal stability does not arise from practical needs. It must have its roots not in reality but in a yearning for something unreal. Which is to say that the widespread notion that law either is or can be made approximately stationary and certain is irrational and should be classed as an illusion or a myth. (Frank, 1930, s. 11-12; wyróżnienie moje)

Tradycyjne teorie prawoznawcze, rozwijające takie podstawowe intuicje na temat prawa jak ta, że prawo stanowi pewną racjonalną, autonomiczną całość albo że stanowi zbiór reguł, które mogą być stosowane w przewidywalny sposób, gwarantując tym samym to, co nazywa się „,bezpieczeństwem prawnym”, były przez realistów oskarżane o różne grzechy, w tym o „marzycielstwo” (wishful thinking), „werbalizm” (verbalism) czy „scholastycyzm" (Paul, 1959, s. 38). Frank pisał zresztą:

We can see now why there is so much talk about the certainty of law. The talk is not descriptive of facts; it is made up of magical phrases. Law being so largely lacking in the certainty which is desired, resort is had to those twangings of the vocal cords which will yield compensatory satisfaction. (Frank, 1930, s. 63; wyróżnienie moje)

Realiści, nawet ci najbardziej radykalni jak Frank, nie kwestionowali zatem istnienia pewnych intuicji i oczekiwań, stojących u podstaw racjonalnych rekonstrukcji pojęcia prawa, które były dokonywane przez tradycyjne teorie prawoznawcze. Choć głównym przedmiotem krytyki były teorie, które deklarowały, że prawo stanowi system reguł (pogląd ten był w na gruncie amerykańskim głoszony między innymi przez Johna Dickinsona, którego realiści tacy jak Beale, Frank i Pound oskarżali o „fetyszyzm reguł”, rule-fetishism; por. Paul, 1959, s. 39), to wydaje się, że był to jedynie szczególny przykład ich nominalistycznej, antyformalistycznej (w szerokim sensie) krytyki, którą można postrzegać jako skierowaną przeciwko wszelkim formom ,scholastycznego" i abstrakcyjnego myślenia o prawie. Zasadniczo traktowali oni jednak intuicje (truizmy o prawie), stojące u podstaw teorii pozytywistycznych, za równie zasadne co intuicje, stojące u podstaw innych teorii i przestrzegali przed absolutyzowaniem jedynych kosztem drugich. Można powiedzieć, że zasadnicza intuicja realistów miała charakter meta-teoretyczny i sprowadzała się do przekonania, że nie wolno absolutyzować żadnej szczególnej formy myślenia o prawie. Jednocześnie było to wezwanie do prawdziwie filozoficznej, bo krytycznej refleksji nad 
założeniami czy wręcz uprzedzeniami, które stały u podstaw popularnych form myślenia prawniczego. Ta uwaga odnosi się nie tylko do form myślenia, które były popularne w Ameryce w pierwszej połowie XX wieku (Langdellizm, formalizm, proste formy pozytywizmu i prawa natury, szkoła legal proces itd.), ale również znajduje zastosowanie w odniesieniu do nowych form ogólnego myślenia o prawie (debata różnych form wyrafinowanego, post-Hartowskiego pozytywizmu z teorią Dworkina i innymi formami niepozytywizmu). Wynika to z umocowania poglądów realistów na podstawach pragmatycznej metodologii (szczególnie związanej z ideami Deweya).

Ponadto w moim przekonaniu to właśnie nominalizm, w filozoficznym znaczeniu, jest jakby paradoksalnie to nie brzmiało zważywszy na tradycyjną opozycję realizm-nominalizm (spór o uniwersalia) - główną cechą realistycznego poglądu na prawo (i inne instytucje społeczne). Należy zatem mieć na uwadze fakt, że realiści prawniczy nie byli wcale realistami w tradycyjnym sensie. Warto też zauważyć, że w oczach krytyków realizmu prawniczego przyjmowany przez realistów prawniczych nominalizm był stanowiskiem absurdalnym, którego akceptacja prowadziła właściwie do przyjęcia ,atomistycznej teorii prawa" (będącej zresztą pewną wersją ogólnej teorii prawa). Zgodnie z tą ostatnią teorią prawo składa się właściwie wyłącznie z pojedynczych, niezależnych decyzji instytucji (sądów, urzędów) wydawanych w sprawach indywidualnych. Taką koncepcję Morris Cohen uznał wprost za „niebezpieczną dla rozwoju nauki prawa”, choć nie kwestionował tego, że tak radykalny pogląd znajduje pewne podstawy (Cohen, 1982, s. 226). Niemniej wydaje się, że nominalizm na gruncie teorii prawa nie musi wcale prowadzić do przyjęcia takiej, atomistycznej teorii (zarzut jest więc nieco na wyrost). Frank, odpowiadając na zarzuty Cohena, zauważył zresztą, że realiści wcale nie twierdzą, że reguły prawne nie istnieją, lecz jedynie, że mają niewielkie znaczenie pr a k t y c z n e (por. Paul, 1959, s. 35, przypis 1). Frank pisał:

The sceptics insist that legal rules exist and must be studied. But they say that knowledge of the rules is but small part of what lawyers and judges use in their work and that a definition of law as rules does an injury to clear thinking about law. (Frank, 1931, s. 44-45)

Celem realistów qua nominalistów było zatem nie tyle podważenie istnienia pewnych bytów instytucjonalnych, takich jak na przykład reguły prawne, ile jedynie zakwestionowanie możliwości przedstawienia jakiejkolwiek praktycznie przydatnej de f i n i c ji prawa czy - i w tym zakresie ich krytyczna postawa może być odniesiona także do współczesnych ogólnych teorii prawa, takich jak post-Hartowski pozytywizm prawniczy - jakiegokolwiek adekwatnego, teoretycznego przedstawienia „natury” bądź „istoty” prawa ${ }^{14}$. Nawet jeśli

\footnotetext{
${ }^{14}$ Odnośnie do możliwości zdefiniowania pojęcia prawa Frank pisał: „Of course, anyone can define ‘law' as he pleases. The word 'law' is ambiguous and it might be well if we could abolish it. But until a substitute is invented, it seems not improper to apply it to that which is central in the work of the practicing lawyer" (Frank, 1930, s. 47). Współcześnie pogląd nominalistyczny wyraża wprost kontynuujący tradycję realistyczną (aczkolwiek w bardziej uporządkowany filozoficznie sposób) Brian Tamanaha, który pisze: „Prawem jest wszystko, do czego stosujemy określenie ,prawo” [label ,law”], a to określenie stosujemy do wielu różnorodnych zjawisk o różnorodnych funkcjach (...)” (Tamanaha, 2001, s. 193). W innym miejscu teoretyk ten zauważył: „Projekt polegający
} 
„natura” prawa nie jest w ich teoriach rozumiana esencjalistycznie (por. Schauer, 2013), to należy przynajmniej uznać, że stawiają one sobie zupełnie inne cele i opierają się na zupełnie innych założeniach metodologicznych. Realiści nie dążyli do przedstawienia tego rodzaju teorii, ponieważ po prostu nie wierzyli, że pojęcie prawa da się przekonująco teoretycznie opisać. Nowoczesne wersje teorii pozytywistycznych (np. Hart, 1994; Coleman, 2001; Shapiro, 2011) stawiają sobie za cel rekonstrukcję treści ogólnego pojęcia prawa. Wydaje się, że teorie pozytywistyczne mogą być postrzegane jako teorie, które rekonstruują pojęcie prawa w oparciu o tak zwaną potoczną teorię prawa (folk theory of law), a więc powszechnie podzielane intuicje i przekonania na temat tego, czym prawo jest (Gizbert-Studnicki, Dyrda, Grabowski, 2016, s. 78 i n.). Tę metodę rekonstrukcji pojęć stosują z mniejszą lub większą ścisłością do analizy ogólnego pojęcia prawa (Shapiro, 2011; Spaak, 2016). Można powiedzieć, że ogólne teorie prawa, a w szczególności współczesne teorie pozytywistyczne, opierają się na jakiejś wersji analizy pojęciowej, która ukierunkowana jest na ujawnienie pewnego społecznego samorozumienia związanego z istnieniem prawa jako artefaktu społecznego (Gizbert-Studnicki, Dyrda, Grabowski, s. 78 i n.). Niemniej jednak w takim razie pragmatycznie motywowane zarzuty pod adresem różnych form analizy pojęciowej pozostają tutaj w mocy (por. Dyrda, 2017). Jak sądzę, przyjęcie przez realistów prawniczych perspektywy nominalistycznej stanowiło realizację tej samej metodologicznej intuicji, która w latach 40. i 50. XX wieku stała u podstaw pragmatycznego programu krytyki analityczności w ogóle (White, 1951; White, 1963; Quine, 1951).

Jeśli w ten sposób spojrzymy na realizm prawniczy, to możemy powiedzieć, że stanowi on teorię, która stawia sobie zupełnie inne cele niż tak zwane ogólne teorie prawa. W najlepszym przypadku realiści prawniczy po prostu ignorują rozważania i analizy, które stanowią codzienność dla przedstawicieli ogólnej jurysprudencji, ewentualnie zaś je odrzucają. Taka interpretacja realizmu nakazuje uznać, że teorie realistyczne i ogólne teorie prawa są od siebie niezależne w tym sensie, że realiści nie muszą zakładać jakiejkolwiek teorii ogólnej, aby prowadzić swoje rozważania, a to dlatego, że tworzenie jakiejkolwiek ogólnej teorii jest z punktu widzenia ich celów po prostu zbędne. Ponadto jeśli przez „założenia” rozumiemy jakieś abstrakcyjne podstawy teorii, od których zależą jej twierdzenia szczegółowe, to realizm prawniczy nie przyjmuje jako swoich założeń twierdzeń ogólnych teorii prawa. Przyjęta przez realistów metodologia pragmatyczna nie pozwala przyjmować jakichkolwiek założeń w inny sposób niż tylko „na próbę”, nie poszukuje ona też żadnych wyjaśnień, które miałaby charakteryzować teoretyczna ,pewność” - a są to cele zakładane przez ogólnych teoretyków prawa. Oznacza to, że ewentualna akceptacja twierdzeń ogólnych teoretyków prawa (w tym - pozytywistów prawniczych) przez realistów może mieć, $\mathrm{z}$ uwagi na specyfikę ich własnej teorii, charakter wyłącznie przygodny. Realizm zatem nie zakłada z konieczności żadnych istotnych twierdzeń takich teorii ani nie dąży do odpowiedzi na pytania, które sobie stawiają. Dlatego uznawanie go za pariasa z opisanych powodów (które odpowiadają wskazanym na wstępie przyczynom drugiej i trzeciej) jest nietrafne.

na wymyśleniu naukowego pojęcia prawa był oparty na błędnym przekonaniu, że prawo stanowi kategorię fundamentalną. Wręcz przeciwnie, prawo jest konstruktem całkowicie kulturowym, pozbawionym jakiejkolwiek istotowej natury" (Tamanaha, 1997; por. Gizbert-Studnicki, Dyrda, Grabowski, 2016, s. 94). 
Pozostaje zatem odpowiedzieć na pytanie o to, czy ignorowanie twierdzeń realistów prawniczych jest zasadne dlatego, że realizm stanowi pewnego rodzaju teorię, która jednak wymyka się klasycznym podziałom teoretycznym i tym samym nie pozwala mu uczestniczyć w najważniejszych dwudziestowiecznych debatach między przedstawicielami „tak zwanej ogólnej jurysprudencji” (przyczyna pierwsza). Jak sądzę, istnieją tutaj dwie możliwości postrzegania realizmu jako nie-ogólnej teorii prawa. Po pierwsze można realizm postrzegać jako prostą, deskryptywną teorię orzekania (i ewentualnie, jeśli przyjmuje się jakąś formę „tezy o zależności” teorii orzekania od teorii ogólnych, dyskutować czy w takiej, a nie innej wersji teoria realistyczna przyjmuje akurat takie, a nie inne założenia pojęciowe). Po drugie można realizm postrzegać jako teorię ogólną, ale w zupełnie innym znaczeniu: jako teorię, która ogólnie kwestionuje twierdzenie, że prawo posiada jakąkolwiek istotę, w związku z czym skupia się na zagadnieniach teoretycznych w obrębie prawoznawstwa możliwych do badania bez dokonywania jakichś głębszych filozoficznych założeń na temat „,natury” prawa ${ }^{15}$. Można także połączyć obie te perspektywy i w konsekwencji traktować realizm jako możliwie deskryptywną teorię działań instytucjonalnych (orzeczniczych), która nie opiera się na żadnych głębszych założeniach pojęciowych dotyczących natury prawa. Jak sądzę, właśnie w taki sposób można ogólnie scharakteryzować podejście realistów amerykańskich.

Nawet jeśli uznamy, że teorie realistyczne stanowią, jak pisze Leiter, deskryptywne teorie orzekania (pozostające w opozycji do formalistycznych teorii orzekania), to relacja tych teorii do teorii ogólnych może być kształtowana na kilka sposobów. Po pierwsze teorie orzekania mogą być związane z teoriami ogólnymi w ten sposób, że teorie ogólne opisujące, czym jest prawo, muszą być przez nie z konieczności założone, aby mogły w jakiś sposób opisywać stosowanie prawa. Zwolennikiem twierdzenia o istnieniu takiej relacji jest właśnie Leiter, który twierdzi, że realiści milcząco zakładają teorię pozytywizmu prawniczego. Po drugie teorie takie jak realizm prawniczy mogą być znacznie luźniej powiązane z teoriami ogólnymi, uwzględniając prezentowane przez nie założenia i twierdzenia jedynie wybiórczo, gdy wymaga tego praktyczna potrzeba. Wreszcie, po trzecie, teorie orzekania - co się tyczy w szczególności realizmu prawniczego - mogą wprost odcinać się od rozstrzygnięć ogólnych teorii prawa, uznając je za przejaw formalizmu w szerokim znaczeniu, na które wskazywałem wcześniej.

W moim przekonaniu za trafne należy uznać dwa ostatnie poglądy, pierwszy zaś należy traktować z daleko idącą ostrożnością. Argumenty sugerujące, że realiści wcale nie zakładali - choćby nieświadomie - jakiejś poważniejszej formy pozytywizmu prawniczego przedstawię za chwilę. W świetle powyższych uwag należy odrzucić z całą stanowczością

\footnotetext{
${ }^{15}$ Nie oznacza to jednak, że w takim rozumieniu realizm prawniczy stanowi realizację ,postawy afilozoficznej” w prawoznawstwie w sensie, jaki terminowi temu nadał Jerzy Wróblewski, to jest postawy, wyrażającej się w braku powołania się na przyjmowane tezy filozoficzno-metodologiczne lub wprost wyraźnym odcinaniu się od wszelkich filozofii (Wróblewski, 2015, s. 35). Realizm będzie raczej „postawą filozoficzną”, gdyż świadomie, z pełną premedytacją przyjmuje nominalizm i metodologię pragmatyczną. Natomiast w przypadku, gdyby charakterystyka realizmu jako milcząco przyjmującego pozytywizm prawniczy okazałaby się trafna, to stanowiłby on realizację ,postawy afilozoficznej”. Jak jednak wskazuję na końcu tego tekstu, argumentacja Leitera jest wadliwa.
} 
rozpowszechnioną opinię, że realizm prawniczy nie tyle stanowił deskryptywną teorię orzekania, ile po prostu sceptyczną teorię prawa. Taki pogląd wyraził Hart, czyniąc z realizmu prymitywną teorię ogólną, starającą się odpowiedzieć na pytanie „czym jest prawo?" (Hart, 1994, s. 136 i n.). Przypisanie realistom intencji odpowiadania na pytanie, na które właściwie nie chcieli oni odpowiadać, wystawiło teorie realistyczne na ataki, których nie mogły one odeprzeć. Nie mogąc w żaden spójny sposób odpowiedzieć na pytania dotyczące natury prawa, racji prawnych czy normatywności prawa, realizm prawniczy zdyskredytowano jako ogólną teorię prawa (a więc w konsekwencji został potraktowany podobnie jak w przypadku krytyki Cohena). Odpadł tym samym już w przedbiegach z wyścigu, w jakim uczestniczyły różne teorie ogólne (pozytywistyczne i niepozytywistyczne), pozostając w cieniu najważniejszych debat między nimi (debata Hart-Fuller, debata Hart-Dworkin; por. Dyrda, 2014b) ${ }^{16}$. Pariasem uczyniły go zatem teoretycznoprawne „kasty wyższe”, które uznawały, że krytyczne spostrzeżenia realistów mogą zostać sformułowane na gruncie ,języka" (siatki pojęciowej) ogólnych teorii prawa ${ }^{17}$.

\section{II}

Leiter (2001) uważa, że w pewnym istotnym sensie realistyczne prawoznawstwo opierało się na założeniach podobnych do tych, które charakteryzują znaturalizowaną epistemologię Williarda V. Quine'a (dlatego skłonny jest on nazywać realizm prawniczy ,jurysprudencją znaturalizowaną"). Jako taki, realizm prawniczy prowadzi „fotelowe analizy pojęciowe” (armchair conceptual analysis), które w szczególny sposób ukierunkowane są na rezultaty badań empirycznych (a posteriori enquiry in empirical sciences; Leiter, 2001, s. 283). W tym rozumieniu realizm prawniczy jest deskryptywną teorią kauzalnych powiązań między określonymi typami sytuacji (obserwacjami faktów) a rzeczywistymi decyzjami sędziowskimi. Zdaniem Leitera istnieje daleko idąca analogia między sposobem myślenia realistów a argumentacją Quine'a, wedle której (1) fundacjonizm epistemiczny jako pogląd charakterystyczny dla tradycyjnej epistemologii filozoficznej, poszukującej kryteriów uzasadnienia dla wiedzy, jest „,przegraną sprawą” i należy go odrzucić, (2) należy odciąć się od poszukującej racji (uzasadnień) tradycji filozoficznej w tym względzie i oprzeć się na psychologii. Skoro bowiem jakiekolwiek racjonalne ,uprawomocnienie" - to jest pewna dedukcja logiczna - nauki (teorii) na podstawie obserwacji nie może mieć miejsca, to należy przyjąć odmienną strategię i po prostu badać empiryczne (kauzalne) relacje między pobudzeniami receptorów zmysłowych (inputs), inferencjami (derywacjami przekonaniowymi)

\footnotetext{
${ }^{16}$ Jeśli spróbować by porównać teorię Dworkinowską i teorie realistyczne, zapewne okazałoby się, że o ile obie przyjmują założenia metodologii pragmatyzmu (i przez to nie są formalistyczne w szerokim sensie), to pierwsza pozostaje - jak wskazałem wcześniej za Leiterem - teorią formalistyczną w wąskim sensie, natomiast teorie realistyczne także tym rozumieniu są radykalnie antyformalistyczne. Przy czym w teorii Dworkinowskiej widoczny będzie charakterystyczny mariaż holistycznego pragmatyzmu z realizmem moralnym (który wedle wielu krytyków jest po prostu nie do utrzymania; por. Dyrda, 2017, s. 401 i n.). Z kolei ogólne rozumienie pozytywizmu zdaje się tych kwestii w ogóle nie przesądzać - można zatem uprawniać pozytywizm „pragmatycznie” i jednocześnie antyformalistycznie bądź formalistycznie (w każdym z przytoczonych wcześniej sensów formalizmu).
}

${ }^{17}$ Omówienie różnych możliwych rozumień realizmu jako „teorii” czytelnik znajdzie w artykule Greena (2005). 
i ich rezultatami w postaci teorii (outputs) $)^{18}$. Oznacza to zatem, że poszukująca uzasadnienia epistemologia klasyczna zostaje zastąpiona czysto deskryptywną, przyczynowo-nomologiczną nauką o ludzkim poznaniu (Kim, 2016, s. 124).

Sugestia Quine’a, aby „poprzestać na psychologii” i „przyjrzeć się temu, jak konstrukcja [teorii na podstawie obserwacji] rzeczywiście przebiega" (Quine, 1969, s. 111; por. Kim, 2016, s. 125), znajduje swój odpowiednik na gruncie ,jurysprudencji znaturalizowanej” w postaci dwóch twierdzeń: (1) odrzuceniu prawnego fundacjonizmu (to jest teorii zgodnie z którą ,racje prawne” miałyby zawsze uzasadniać decyzję podejmowaną w procesie stosowania prawa) i (2) przedstawieniu alternatywnego, opisowego, nie-uzasadniającego ujęcia procesów stosowania prawa. Nie ma tutaj miejsca, aby dokładnie przedstawić pieczołowitą argumentację Leitera i poddać ją krytyce, na jaką niewątpliwie zasługuje. Dlatego ograniczę się do kilku uwag, które przynajmniej wstępnie uzasadniają podejrzenie, że taka interpretacja realizmu może nie być trafna.

Jeśli chodzi o tezę pierwszą (odrzucenie fundacjonizmu), to z całą pewnością teza ta zostaje przypisana przez Leitera realistom w postaci relatywnie słabszej, niż ma to miejsce w przypadku argumentacji Quine'a. Dan Priel zwraca uwagę, że o ile Quine wyklucza w ogóle możliwość uprawiania racjonalnej, normatywnej, nie-znaturalizowanej epistemologii (w każdym możliwym świecie; jest to n i e m o żli we), to Leiter przypisuje realistom słabszą tezę, zgodnie z którą rzeczywis te praktyki sędziów, urzędników, prawników itd. nie mają charakteru fundacjonistycznego (to, że nie ma rzeczywistych przykładów takich praktyk, wcale przecież nie wyklucza, że są one możliwe; Priel, 2008, s. 316 i n.). Ponadto, jeśli (zgodnie z założeniami Quine’a) za fundacjonizm w epistemologii uznamy pogląd, że istnieje jakaś forma pierwotnej wiedzy nie-inferencyjnej, z której możemy derywować teoretyczną wiedzę wtórną, to jego odpowiednikiem na gruncie teorii prawa będzie pogląd, że normy prawne są pr a w ne właśnie dlatego, że zostały wyinferowane (w jakiś dopuszczalny sposób) z norm pierwotnych (Priel, 2008, s. 318). W jaki sposób, to już jest kwestia drugorzędna (choć zasadniczo chodzi tu o dwa rodzaje powiązań inferencyjnych: treściowe i kompetencyjne, to jest odpowiednio statyczne i dynamiczne $\mathrm{w}$ kelsenowskim sensie). $\mathrm{Z}$ kolei $\mathrm{w}$ ramach tak rozumianego fundacjonizmu możliwe jest wyróżnienie poglądu formalistycznego (w ścisłym sensie, zgodnie z którym z a w s ze, to jest w każdym przypadku orzekania, da się wyprowadzić normy prawne stanowiące właściwą odpowiedź na pytanie „co X powinien zrobić w okolicznościach Y?”), jak i nieformalistycznego (zgodnie z którym prawo nie jest z konieczności zdeterminowane, normy prawne zaś stanowią podstawę orzekania, o ile da się je wyprowadzić z norm pierwotnych de lege artis). Przykładowo pozytywiści prawniczy z całą pewnością są fundacjonistami (z uwagi na to, że przyjmują jakąś teorię normy/reguły bazowej, to jest konwencjonalną regułę uznania albo transcendentalną normę podstawową), lecz kwestia formalizmu pozostaje u nich (jak wskazywałem wcześniej) otwarta, a faktycznie pozytywiści nie przyjmują poglądu formalistycznego.

\footnotetext{
${ }^{18}$ Więcej na temat tzw. epistemologii znaturalizowanej czytelnik znajdzie w szczególności w dziele Quine’a (1969), a rzetelną rekonstrukcję założeń programu Quine'a - w artykule Kima (2016).
} 
Zastanówmy się teraz nad adekwatnością przeprowadzanej przez Leitera analogii. Gdyby analogia do twierdzeń Quine'a miała być przeprowadzona ściśle, to wymagałaby ona przyjęcia, że w ogóle nie istnieją żadne racje prawne, a w szczególności normy czy reguły pierwotne, które mogłyby stanowić u z a s a d n i e n i e dla decyzji sędziowskich. Priel zauważa, że w tej kwestii sam Leiter (w różnych swoich pracach) nie był szczególnie ścisły, gdyż czasami przyjmował tę mocną wersję analogii, a czasami słabszą, zgodnie z którą prawo nie jest z konieczności zdeterminowane przez „racje prawne”, sugerując jednak, że może być determinowane, choćby jedynie w pewnym stopniu przez inne rodzaje racji (Priel, 2008, s. 319-320). Różnica ta ma istotne znaczenie z punktu widzenia oceny wiarygodności naczelnego twierdzenia Leitera, że realiści prawniczy zakładali pozytywizm prawniczy. Ścisła analogia do myśli Quine’a nakazywałaby przecież uznać, że racje prawne w zasadzie nie istnieją, bo nie ma niczego, co może u z a s a d n i a ć, choćby częściowo, decyzje prawne (jako prawne właśnie). W takiej sytuacji na przykład to, co pozytywiści rozumieją przez „racje prawne”, musiałoby zostać uznane - w przypadkach, w których sędziowie kierowaliby się nimi w orzekaniu - po prostu za jakiegoś rodzaju przyczyny, których nie można traktować jako czegoś, co r a c j o n a li z u j e ich decyzje. Twierdzenie uzupełniające mogłoby w tym ujęciu brzmieć dwojako: albo przyjąć formę argumentu (2'), zgodnie z którym teoria realistyczna była faktycznie teorią czysto kauzalnych powiązań między takimi przyczynami i decyzjami, albo przyjąć postać argumentu (2'), zgodnie z którym nawet jeśli decyzje orzecznicze nie są u za s a n i o ne przez jakieś racje prawne (bo te nie istnieją), to bywają faktycznie uzas a nione przez pewne inne typy racji, na przykład racje moralne (tak zwane non-legal reasons). W tym drugim przypadku analogia jednak znów okazuje się analogią słabszą, ponieważ mimo zakwestionowania istnienia racji prawnych dopuszcza się możliwość jakiegoś u z a s a d n i e n i a działalności orzeczniczej sędziów itd. Jeśli natomiast uznać, że realizm prawny był teorią ,znaturalizowaną” w takim sensie, w jakim epistemologia była znaturalizowana dla samego Quine'a, to należy nie tylko przyjąć, że racje prawne nie istnieją, ale także, że w ogóle nie istnieją żadne racje, które racj on a li z u ją decyzje sędziów. Oznacza to nie tylko, że nie istnieje żadna autonomiczna domena reguł (racji) prawnych, lecz również, że nie istnieje żadna domena racji, które uzasadniają decyzje sędziowskie. Jeśli weźmiemy pod uwagę to, że zasadniczym dążeniem ogólnych teorii prawa, w szczególności zaś teorii pozytywistycznych, jest wyjaśnienie roli, jaką normy prawne odgrywają w praktycznej deliberacji podmiotów (co wiąże się z wyjaśnieniem normatywności, autorytetu prawa), to nie mamy innego wyjścia jak uznać, że realizm prawniczy nie może akceptować żadnych zasadniczych twierdzeń teorii pozytywizmu prawniczego, a tym bardziej - ich zakładać.

Wydaje się zatem, że jedynie przyjęcie, iż ścisła analogia Quine’owska z „epistemologii znaturalizowanej" jest nietrafna, pozwala uzasadnić twierdzenie, że realiści prawniczy w jakiś sposób zakładali pozytywizm prawniczy (Priel, 2008, s. 321-322). Dokładniejsze zbadanie argumentacji Leitera w tej mierze to potwierdza. Kluczowe znaczenie ma tutaj przeprowadzona przez niego analiza centralnego twierdzenia realistów, jakim jest twierdzenie o niezdetermiowaniu prawa (indeterminacy of law). 
Argumentację Leitera na rzecz twierdzenia, że realiści zakładali ogólną teorię pozytywistyczną (w twardo-pozytywistycznej, ekskluzyjnej, to jest „wyłączającej” wersji ${ }^{19}$ ), można zrekonstruować w postaci następujących twierdzeń: (1) realiści argumentowali na ogół, że racje prawne są zwykle niezdeterminowane (nieokreślone, indeterminate), (2) argument realistów opiera się na pojęciowej dystynkcji racji prawnych (legal reasons) i racji poza-prawnych (extra-legal reasons) bądź prawnych i poza-prawnych źródeł (podstaw) decyzji sędziowskich - w przypadku pierwszego rodzaju źródeł wskazuje się na ustawy i precedensy, (3) tylko (twarda, ekskluzyjna) wersja pozytywizmu prawniczego pozwala przeprowadzić takie odróżnienie, a zatem (4) realiści byli pozytywistami prawniczymi (Leiter, 2001, passim; por. Priel, 2008, s. 324). Warto dodać, że twierdzenie Leitera można także przedstawić w postaci warunkowej: jeśli twardy pozytywizm nie okazałby się prawdziwy, to argument realistów dotyczący niezdeterminowania prawa opiera się na fałszywej przesłance, a zatem sam jest nietrafny (por. Priel, 2008, s. 325).

Jak widać, wedle Leitera podstawowym założeniem realistów było twierdzenie, związane z pewną podstawową intuicją na temat prawa (należącą zapewne do jakiejś folk theory of law), że możliwe jest odróżnienie prawnych i pozaprawnych podstaw decyzji sędziowskich. Priel nazywa, nieco zresztą na wyrost, ten pogląd ,pozytywizmem źródeł” (positivism of sources; Priel, 2008, s. 346 i n.). Trudno jednak uznać to twierdzenie nawet za zarzewie poważnej teorii pozytywistycznej, która ma nie tylko odpowiedzieć na pytanie o źródła prawa (tak czy inaczej określone), ale również między innymi wyjaśniać ich normatywny charakter (por. Dyrda, 2013).

Jeśliby natomiast zapytać, czy realiści rzeczywiście uznawali, że istnieją jakieś „racje”, które pozwalają racjonalizow ać podejmowane przez sędziów decyzje, to wydaje się, że rozstrzygnięcie tej kwestii zależy po prostu od tego, czyje poglądy zdecydujemy się przeanalizować. Funkcjonalizm Pounda, wprowadzający pewne formy opartych na wartościach rozumowań celowościowych, stanowi wezwanie do nieustannej walki z toczącą dyskurs prawny, nieusuwalną irracjonalnością. Z kolei realizm w wersji Franka, z właściwym sobie sceptycyzmem zarówno co do roli reguł, jak i faktów, wzywa po prostu do ujawniania rzeczy wisty ch przyczyn podejmowania decyzji sędziowskich, pełniąc przy tym funkcję demaskatorską (ujawniając fałszywe i szkodliwe podświadome bądź intuicyjne przekonania, których likwidacja co prawda nie przywróci racjonalności w dyskusjach o prawie, ale przynajmniej ograniczy ich zakres). Między tymi dwoma nurtami interpretatorów myśli Holmesa znajdujemy wiele innych poglądów realistycznych, między innymi twierdzenie, że sędziowie wtórnie racjonalizują swoje decyzje przez odwołanie się do reguł (pogląd ten wyraził Holmes już w The Path of the Law;

\footnotetext{
${ }^{19}$ Twardy pozytywizm to, mówiąc możliwie lakonicznie, teoria, zgodnie z którą w każdym możliwym przypadku systemu prawa to, co jest prawem, może być jasno zidentyfikowanie wyłącznie poprzez odwołanie się do źródeł społecznych. Jakiekolwiek odwołanie się do innych źródeł (moralnych, idei sprawiedliwości itd.) stanowi wyjście poza autonomiczną domenę prawa, będąc tym samym odwołaniem się do racji poza-prawnych (na temat różnych wersji pozytywizmu, inkluzyjnej, ekskluzyjnej i etycznej por. Dyrda, 2013, s. 94-148).
} 
por. Holmes, 1987 ${ }^{20}$. W przypadku tego ostatniego poglądu reguły zostają docenione na tyle, na ile jest to u realistów w ogóle możliwe: uznaje się ich istnienie, wynikające z pewnej praktycznej potrzeby, jednocześnie przypisywana im w bardziej tradycyjnych sposobach myślenia o prawie rola zostaje zakwestionowana.

Ponadto, nawet w sytuacjach gdy realiści mówili o źródłach prawnych i poza-prawnych decyzji, to określenie ,prawny” w pierwszym przypadku niekoniecznie musiało wynikać z przyjęcia przez nich jakiejś ogólnej pre-koncepcji prawa, ale mogło jedynie oddawać pewną potoczną intuicję, akceptowaną zresztą także przez niepozytywistyczne teorie prawa. Nawet jeśli realiści czasami ulegali takim tradycyjnym sposobom mówienia, nie oznacza to zatem, że tego rodzaju wypowiedzi mogą stanowić podstawę dla formułowania tak śmiałych tez. Wszak ich nominalistyczne nastawienie, testowane w pragmatycznym procesie „osądu i błędu” (trial and error) nakazuje wątpić w to, by traktowali jakiekolwiek tego rodzaju klasyfikacje podstaw decyzji jako coś więcej niż przygodne, przydatne „etykietki”, z których w razie potrzeby, w każdej chwili można zrezygnować.

\section{III}

Oddajmy na koniec głos jeszcze raz Frankowi:

... A rule tells something about law, but is not law. For, to repeat, law is what happened or what will happen in concrete cases. Past decisions are experimental guides to prognostications of future decisions. And legal rules are mental devices for assembling, in convenient forms, information about past cases to aid in making such prognostications. Or they may be defined as generalized statements of how courts will decide questions, of the considerations which will weigh with courts in the decision of cases to which the rules are applicable (Frank, 1930, s. 276; wyróżnienie moje).

Jak sądzę, twierdzenie Leitera, że realiści zakładali pozytywizm prawniczy, samo znajduje oparcie w fakcie, że wypowiada je pozytywista, czyli ktoś, kto pojęciowo odróżnia dwie domeny normatywne: racji prawnych i racji pozaprawnych. Podobne podejrzenie wysuwa Priel (2008, s. 347). Nawet jeśli rozumieć te racje na sposób deskryptywny, to jest jako przyczyny (causes), które determinują decyzje sędziowskie (a nie - uzasadniają je), to samo przyjęcie ogólnej tezy o istnieniu autonomicznej domeny „racji prawnych” wpływa już na postrzeganie twierdzeń realistów prawniczych na temat czynników determinujących decyzje sędziowskie jako takich, które zakładają pozytywistyczne pojęcie prawa. Jest to jednak

\footnotetext{
${ }^{20}$ Holmes pisał między innymi: "The language of judicial decision is mainly the language of logic. And the logical method and form flatter that longing for certainty and for repose which is in every human mind. But certainty generally is illusion, and repose is not the destiny of man. Behind the logical form lies a judgment as to the relative worth and importance of competing legislative grounds, often an inarticulate and unconscious judgment, it is true, and yet the very root and nerve of the whole proceeding. You can give any conclusion a logical form. You always can imply a condition in a contract. But why do you imply it? It is because of some belief as to the practice of the community or of a class, or because of some opinion as to policy, or, in short, because of some attitude of yours upon a matter not capable of exact quantitative measurement, and therefore not capable of founding exact logical conclusions." (Holmes, 1897).
} 
nadużycie, a to dlatego, że realistom - właśnie z uwagi na ich pragmatyczne podejście i nominalizm - w zasadzie było wszystko jedno, czy i w jaki sposób dokona się klasyfikacji tych czynników, a także co będzie się rozumieć pod pojęciem racji prawnych i racji pozaprawnych. Wszystkie one razem stanowią dla nich przede wszystkim przyczyny podejmowania decyzji sędziowskich, pierwsza ich grupa została zaś tradycyjnie wyróżniona (,prawne”) ze względu na zasadnicze znaczenie dla wtórnej racjonalizacji tych decyzji.

Na koniec chciałbym podkreślić, że w moim przekonaniu najtrafniejszą interpretacją realizmu prawniczego jest potraktowanie go jako możliwie deskryptywnej teorii działań instytucjonalnych (orzeczniczych), która nie opiera się na żadnych głębszych założeniach pojęciowych dotyczących natury prawa, w tym - „racji prawnych”. Nie wyklucza to jednak wcale możliwości przygodnej akceptacji przez realistów pewnych twierdzeń pozytywistycznych (czy szerzej: ogólnoteoretycznych). Realizm stanowi zatem raczej refleksyjną (krytyczną) i interesującą alternatywę dla tradycyjnych sposobów myślenia o prawie aniżeli bezrefleksyjnego i dziecinnego ich rywala, którego można po prostu zignorować.

\section{Bibliografia}

Arnold, T. (1937). The folklore of capitalism. New Haven, CT: Yale University Press.

Beard, C. (1921). An economic interpretation of the Constitution of the United States. New York, NY: The Macmillan Company.

Cohen, M. (1982). Law and the social order: Essays in legal philosophy. New Brunswick, NJ: Transaction Books.

Dewey, J. (1891). The present position of logical theory. Monist, 2(1), 1-17.

Dewey, J. (1899). The school and society. New York, NY: McClure, Phillips.

Dewey, J. (1929). The quest for certainty. New York, NY: Minton, Balch \& Company. Retrieved from: https://archive.org/stream/questforcertaint032529mbp/questforcertaint032529mbp_djvu.txt

Douglas, W., Shanks, C. M. (1929). Insulation from liability through subsidiary corporations. Yale Law Journal, 39, 1935-1921.

Dyrda, A. (2013). Konwencja u podstaw prawa: Kontrowersje pozytywizmu prawniczego. Warszawa: Wolters Kluwer.

Dyrda, A. (2014a). Momosa pragmatyzm prawny: Rzeczywiste granice teorii, rozsądne granice krytyki. Jurysprudencja, 2, 149-162.

Dyrda, A. (2014b). Spór o pojęcie prawa - debaty Hart-Dworkin ciąg dalszy? Państwo i Prawo, 69(4), $3-18$.

Dyrda, A. (2015). Pragmatism, holism and the concept of law. Erasmus Law Review, 1, 2-13.

DOI: http://dx.doi.org/10.5553/ELR.000034 
Dyrda, A. (2017). Spory teoretyczne w prawoznawstwie: Perspektywa holistycznego pragmatyzmu. Warszawa: Wydawnictwo Scholar.

Frank, J. (1930). Law and the modern mind. New York, NY: Coward-McCann.

Frank, J. (1931). Are judges human? University of Pennsylvania Law Review and American Register, $80,17-53 ; 233-267$.

Frank, J. (1932). Mr. justice Holmes and non-euclidean legal thinking. Cornell Law Quarterly, 17, 568-603.

Gizbert-Studnicki, T., Dyrda. A., Grabowski, A. (2016). Metodologiczne dychotomie. Krytyka pozytywistycznych teorii prawa, Warszawa: Wolters Kluwer.

Green, L. (2009). Legal positivism. W: E. N. Zalta (red.), Stanford Encyclopedia of Philosophy (Fall 2009 Edition). Pobrane 1 lutego 2017 z: http://plato.stanford.edu/entries/legal-positivism

Green, M. S. (2005). Legal realism as theory of law. William and Mary Law Review, 46(6), 19152000.

Hamilton, W. (1929). Affectation with a public interest. Yale Law Journal, 39, 1089-1112.

Holmes, O. W., Jr. (1897). The path of the law. Harvard Law Review, 10, 457-478.

Kim, J. (2016). Czym jest epistemologia znaturalizowana? Roczniki Filozoficzne, 64(3), 115-141.

Leiter, B. (1999). Positivism, formalism, realism. Columbia Law Review, 99(4), 1138-1164.

Leiter, B. (2001). Legal realism and legal positivism reconsidered. Ethics, 111(2), 278-301.

Llewellyn, K., Hoebel, E. A. (1941). The Cheyenne way: Conflict and case law in primitive jurisprudence. Norman: University of Oklahoma Press.

Moore, M. (2012). The various relations between law and morality in contemporary legal philosophy. Ratio Juris, 25(4), 435-471.

Paul, J. (1959). The legal realism of Jerome N. Frank: A study of fact-skepticism and the judical process. The Hague, The Netherlands: Martinus Nijhoff.

Peirce, C. S. (1878). How to make our ideas clear. Popular Science Monthly, 12, 286-302. Pobrane z: http://www.peirce.org/writings/p119.html

Pound, R. (1946). Interpretations of legal history. Cambridge, MA: Harvard University Press.

Priel, D. (2008). Were the legal realists legal positivists. Law and Philosophy, 27(4), 309-350.

Quine, W. V. (1951). Two dogmas of empiricism. The Philosophical Review, 60, $20-43$.

Quine, W. V. (1969). Ontological relativity and other essays. New York, NY: Columbia University Press.

Raz, J. (2004). Incorporation by law. Legal Theory, 1(10), 1-17.

Robinson, J. H. (1908). History. New York, NY: Columbia University Press.

Schauer, F. (2004). The limited domain of law. Virginia Law Review, 90(7), 1909-1956.

Schauer, F. (1996). Positivism as pariah. W: R. P. George (red.), The autonomy of law: Essays on legal positivism. Oxford, UK: Oxford University Press. 
Schauer, F. (2013). Hart's Anti-Essentialism. W: A. Dolcetti, L. Duarte d'Almeida, J. Edwards (red.), Reading HLA Hart's 'The Concept of Law' (s. 237-246). Oxford, UK: Hart Publishing.

Shapiro, S. (2011). Legality. Cambridge, MA: Harvard University Press.

Spaak, T. (2016) The Canberra plan and the nature of law. W: P. Banaś, A. Dyrda, T. Gizbert-Studnicki (red.), Metaphilosophy of law (s. 81-119). Oxford, UK: Bloomsbury.

Szubka, T. (2012). Neopragmatyzm. Toruń: Wydawnictwo Naukowe Uniwersytetu Mikołaja Kopernika.

Tamanaha, B. (1997). Realistic socio-legal theory: Pragmatism and a social theory of law. Oxford, UK: Oxford University Press.

Tamanaha, B. (2001). A general jurisprudence of law and society, Oxford, UK: Oxford University Press.

White, M. (1949). Social thought in America: The revolt against formalism. New York, NY: Viking Press.

White, M. (1950). Analytic-synthetic: An untenable dualism. W S. Hook (red.), John Dewey: Philosopher of science and freedom (s. 316-330). New York, NY: Dial Press.

White, M. (1963). Toward reunion in philosophy. New York, NY: Atheneum.

White, M. (2002). A philosophy of culture: The scope of holistic pragmatism. Princeton, NJ: Princeton University Press.

Wróblewski, J. (2015). Pisma wybrane. (M. Zirk-Sadowski, red.). Warszawa: Wolters Kluwer.

Veblen, T. (1898). Why is economics not an evolutionary science? Quarterly Journal of Economics, 12(4), 373-397.

\title{
Legal Realism and Legal Positivism
}

\begin{abstract}
American legal realism is commonly treated as a theory-pariah. The article exposes certain reasons explaining such a treatment. Generally, it seems that such an attitude is a result of many misunderstandings of realist aims and ambitions, some of which pertain to the theoretical status of legal realism and its relation to so called general jurisprudential theories, such as legal positivism. In the first part of the article I explain generally what these aims were and how one should see these relations. In the second part I briefly analyze B. Leiter's famous claim that legal realism is conceptually dependent on hard legal positivism (as a general theory of law). The critique of this claim opens the possibility for some alternative understanding of legal realism.
\end{abstract}

Keywords: legal positivism; American legal realism; legal truisms; general theory of law; theory of adjudication; Brian Leiter. 